\title{
Achalasia During Pregnancy: Proposed Management Algorithm Based on a Thorough Literature Review
}

\author{
Sergei Vosko, ${ }^{1}$ Daniel L Cohen, ${ }^{1 *}$ Ortal Neeman, ${ }^{2}$ Shai Matalon, ${ }^{1}$ Efrat Broide, ${ }^{1}$ and Haim Shirin ${ }^{1}$ \\ ${ }^{I}$ The Gonczarowski Family Institute of Gastroenterology and Liver Diseases, Shamir (Assaf Harofeh) Medical Center (associated with the Sackler \\ School of Medicine, Tel Aviv University), Zerifin, Israel; and ${ }^{2}$ Division of Maternal Fetal Medicine, Institute of Gynecology and Obstetrics, \\ Assuta Hospital, Ashdod, Israel
}

Fewer than 40 cases of achalasia occurring in pregnant woman have been reported in the literature. Given the rarity of achalasia during pregnancy, and the numerous treatment options that are available for achalasia in general, no guidelines exist for the management of achalasia during pregnancy. Diagnosis of new cases may be difficult as symptoms and physiological changes that occur during pregnancy may obscure the clinical presentation of achalasia. The management of achalasia in pregnancy is also challenging. Treatment decisions should be individualized for each case, considering both the welfare of the mother and the fetus. Since pregnant women suffering from achalasia represent a diagnostic and therapeutic challenge with complex maternal-fetal aspects to consider, we have reviewed the available literature on the subject and summarized current diagnostic and therapeutic options. Additionally, we present a management algorithm as a means to guide treatment of future cases. We recommend that a conservative approach should be adopted with bridging therapies performed until after delivery when definitive treatment of achalasia can be more safely performed.

(J Neurogastroenterol Motil 2021;27:8-18)

Key Words

Esophageal achalasia; Disease management; Pregnancy

gered by viral infection, in genetically susceptible individuals. ${ }^{2}$

\section{Introduction}

Achalasia is characterized by destruction of the smooth muscle ganglion cells of the myenteric plexus of Auerbach resulting in esophageal body motor dysfunction, incomplete lower esophageal sphincter (LES) relaxation, and progressive esophageal dilation. Clinically, patients complain of dysphagia to solid foods and liquids, heartburn, regurgitation, vomiting, chest pain, and weight loss. ${ }^{1}$ Recent data suggests that the disease process involves an interaction between autoimmune and inflammatory responses, possibly trig-

\section{Relationship Between Pre-existing Achalasia and Fertility}

Mayberry et $\mathrm{al}^{3}$ surveyed 36 women with achalasia and compared them to 36 age-matched controls. The study found no difference in the number of conceptions or live births between the groups, including both in the time before achalasia was diagnosed and after it was symptomatic. They concluded that achalasia presented no hindrance to becoming pregnant. ${ }^{3}$ A study by Vogel et al ${ }^{4}$

Received: August 13, 2020 Revised: September 30, 2020 Accepted: November 10, 2020

(a) This is an Open Access article distributed under the terms of the Creative Commons Attribution Non-Commercial License (http://creativecommons. org/licenses/by-nc/4.0) which permits unrestricted non-commercial use, distribution, and reproduction in any medium, provided the original work is properly cited.

*Correspondence: Daniel L Cohen, MD

The Gonczarowski Family Institute of Gastroenterology and Liver Diseases, Shamir (Assaf Harofeh) Medical Center, Zerifin 70300, Israel

Tel: +972-58-507-2773, Fax: +972-8-977-9727, E-mail: docdannycohen@yahoo.com 
of 43 women also found no correlation between achalasia and fertility.

A recent study evaluated women that had already undergone peroral endoscopic myotomy (POEM) as treatment for achalasia. They reported that 5 women had become pregnant afterwards (for a total of 7 pregnancies), and concluded that achalasia treated by POEM did not negatively impact future conception. ${ }^{5}$

\section{Relationship Between Pregnancy and the Onset of Achalasia}

Recent studies have shown that an 8-residue insertion in HLA$\mathrm{DQ} \beta 1$ is a genetic risk factor for achalasia. Interestingly, Becker et $\mathrm{al}^{6}$ found that pregnancy itself may be a disease-triggering factor in women carriers of this insertion. Further investigation of this risk is needed especially as other studies have not found any correlation between pregnancy and the onset of achalasia. ${ }^{4}$

\section{Clinical Presentation of Achalasia During Pregnancy}

The diagnosis of achalasia during pregnancy is often difficult because the typical symptoms of achalasia, such as regurgitation and heartburn, can occur early in pregnancy. Frequently, pregnant women presenting with recurrent vomiting are assumed to have hyperemesis gravidarum (HG). Many patients who were eventually diagnosed with achalasia were initially mistakenly diagnosed with HG. Consequently, the diagnosis of achalasia may be delayed until patients present with more advanced disease or life-threatening complications.

Patients with known achalasia can have variable disease courses during pregnancy. A recent study including 18 women with preexisting achalasia reported that 8 of them claimed that their symptoms worsened during pregnancy, while 7 had no change and 3 had an improvement in symptoms. ${ }^{4}$

An older study by Mayberry et $\mathrm{al}^{3}$ described 16 women with pre-existing achalasia. They found that 3 women reported that their symptoms worsened during pregnancy, but 11 had no change, and 2 had an improvement. ${ }^{3}$

Several theories have been suggested as to how pregnancy may affect achalasia symptoms. It has been suggested that increased intra-abdominal pressure and elevation of the diaphragm may affect the esophagus. Also, increased progesterone during pregnancy may reduce smooth muscle motility and tone in the gastrointestinal tract. However, these theories have not been proven and remain specula- tive. ${ }^{4}$

\section{Diagnosis of Achalasia During Pregnancy -}

\section{Manometry}

An assessment of esophageal motor function by high-resolution manometry (HRM) is recommended to confirm the diagnosis of achalasia. ${ }^{7}$ It is the gold standard test for confirming the diagnosis of achalasia. ${ }^{1}$ Further, HRM can classify achalasia into 3 subtypes (Type 1: classic achalasia with aperistalsis, Type 2: achalasia with panesophageal pressurization, and Type 3: achalasia with spasm) which have prognostic value as outcomes differ with regards to various therapies. ${ }^{1}$ While it may be uncomfortable, HRM is a safe diagnostic test during pregnancy, with no risk of teratogenicity. Unfortunately, there are no HRM values specifically for pregnant woman. The only study assessing manometric values in pregnant women is from 1978. This study, using conventional line-tracing manometry, revealed that esophageal peristalsis in pregnant women has lower wave speed and lower amplitude compared to non-pregnant women. ${ }^{8}$

\section{Radiology}

The preferred radiological evaluation for achalasia is a barium esophagram. The classic finding on an esophagram is a dilated esophagus with a tapering at the esophagogastric junction ("bird's beak" sign). ${ }^{1}$ A timed barium esophagram, in which the height of barium that remains in the esophagus is assessed at various time intervals, may provide evidence as to the severity of the case and predict response to treatment. ${ }^{1}$ Other radiographic exams, such as a chest X-ray of CT scan, may show a dilated or tortuous esophagus, or residual food in the esophagus.

The choice of radiological modality in a pregnant woman has to take 2 factors into consideration; the accuracy of the test and minimizing least radiation exposure to the fetus. According to the American College of Obstetricians and Gynecologists' Committee on Obstetric Practice, with few exceptions, radiation exposure through radiography and CT scans is at a dose much lower than the exposure associated with fetal harm. They conclude that if these tests are necessary, they should not be withheld from a pregnant patient. $^{9}$

\section{Endoscopy}

The primary role of endoscopy in the workup of achalasia is to exclude a mechanical obstruction causing pseudoachalasia. ${ }^{2}$ Endo- 
scopic findings in achalasia may range from a seemingly normal examination to a tortuous dilated sigmoid-shaped esophagus, retained food and secretions, and ulcerations secondary to stasis or candida infection. Endoscopy is relatively safe for the fetus and may be performed when strongly indicated during pregnancy. ${ }^{10,11}$ Fetal risks from endoscopic medications can be minimized by avoiding Food and Drug Administration category D drugs and anesthesiologist attendance at endoscopy.

\section{Management of Achalasia}

The main goal of all existing therapies in achalasia is to improve esophageal emptying, relieve symptoms, and prevent long-term complications. In addition, many patients with achalasia present with malnutrition due to their symptoms. In pregnant patients, where fetal development is negatively impacted by malnutrition, ensuring adequate nutritional support is especially important. Therapeutic options for non-pregnant patients can be divided into nutritional support, medical treatment, endoscopic treatment, and surgical treatment. Case reports using these various treatment options are summarized in Table $1,^{12-39}$ while these modalities themselves are summarized in Table 2.

\section{Nutritional Support Treatments}

\section{Parenteral Nutrition}

Parenteral nutrition $(\mathrm{PN})$ is a means of maintaining or restoring nutrition via an intravenous route when oral enteral routes are not feasible. ${ }^{40} \mathrm{PN}$ during pregnancy has been used most often to provide adequate nutrition for those who suffer from prolonged hyperemesis or who have difficulty absorbing adequate nutrients because of such conditions such as Crohn's disease. ${ }^{41}$

Sufficient clinical experience suggests that $\mathrm{PN}$ is a relatively safe and effective method for reversing maternal malnutrition and promoting normal fetal growth and development. Pregnancy outcomes among 122 women diagnosed with HG who received total parenteral nutrition support during early pregnancy showed a decreased risk for perinatal morbidity. ${ }^{42} \mathrm{PN}$ has proved to be helpful in malnourished pregnant women and promotes fetal growth. ${ }^{43}$ It can be used as long as needed throughout the pregnancy, until delivery of the baby.

Potential complications of PN include line complications (occlusion, sepsis, venous thrombosis, and pulmonary embolism) and cholestasis, which may be associated with sepsis. ${ }^{44}$ Given the risks, there should be a clear need for PN before using this modality. ${ }^{45}$

\section{Nasogastric Tube Feedings}

Nasogastric tube (NGT) intubation for feeding during pregnancy is generally well tolerated by the mother, with only rare and mild maternal complications, and with mostly favorable fetal outcomes. $^{46}$ Insertion of the NGT may be more difficult in a patient with achalasia, and endoscopic assistance may be needed.

\section{Percutaneous Endoscopic Gastrostomy Feedings}

As an alternative, Godil and $\mathrm{Chen}^{47}$ described 2 cases of percutaneous endoscopic gastrostomy (PEG) placement in 2 conscious pregnant women with HG. However, PEG tubes do not reduce the symptoms or risks of aspiration of salivary retention. PEG placement also requires the use medications including sedatives, painkillers, and antibiotics, all of which may have risks to the mother or fetus. For all of these reasons, PEG does not appear to be a promising option in pregnant women, and there are no reports of its use in pregnant women with achalasia.

\section{Medical Treatments}

\section{Oral Pharmacological Therapies}

Pharmacological treatment for achalasia is aimed at reducing LES pressure, thereby facilitating passage of esophageal contents into the stomach. The 2 most commonly employed medications are calcium channel blockers and long-acting nitrates, both category $\mathrm{C}$ pregnancy risk. ${ }^{48}$ Sildenafil, a phosphodiesterase-5-inhibitor (Category B), is another option. ${ }^{49}$ Less commonly used medications include anticholinergics (Category $\mathrm{B}$ and $\mathrm{C}$ ), $\beta$-adrenergic agonists (Category $\mathrm{C}$ ), and theophylline (Category $\mathrm{C}$ ). In addition to risks to the fetus, the efficacy of these medications is generally poor and there are potential side effects for the patient. Use of these medications for treatment of achalasia is rare nowadays.

\section{Endoscopic Treatments}

\section{Botulinum Toxin Injection}

Botulinum toxin type A (BTX-A) is a purified neurotoxin from the bacterium Clostridium botulinum. It is used to treat a variety of conditions of increased muscle tone, including achalasia, where it is injected into the LES. ${ }^{50}$ Since BTX-A is a large protein with a high molecular weight $(150 \mathrm{kDa})$, when injected locally in recom- 
Table 1. Case Reports of Achalasia in Pregnant Women With the Type of Treatment and Pregnancy Outcome

\begin{tabular}{|c|c|c|c|c|}
\hline $\begin{array}{l}\text { Publication } \\
\text { (Author and year) }\end{array}$ & $\begin{array}{l}\text { Patient age }(\mathrm{yr}) / \\
\text { gestation }(\mathrm{wk})\end{array}$ & $\begin{array}{l}\text { How achalasia } \\
\text { was diagnosed }\end{array}$ & $\begin{array}{l}\text { Type of achalasia } \\
\text { treatment }\end{array}$ & $\begin{array}{l}\text { Delivery and } \\
\text { outcome }\end{array}$ \\
\hline Roques, $1932^{12}$ & 25 & $\mathrm{BE}$ & $\mathrm{BD}$ & $\begin{array}{l}\text { Preterm labor with fetal and } \\
\text { maternal deaths }\end{array}$ \\
\hline Roques, $1932^{12}$ & 37 & BE, EGD & $\mathrm{BD}$ & Termination at $16 \mathrm{wk}$ \\
\hline Lindert, $1956^{13}$ & 32 & $\mathrm{BE}$ & No treatment & Cesarean section \\
\hline Stroup, $1961^{14}$ & 27 & EGD, BE & Medical treatment & Normal spontaneous delivery \\
\hline Bloomfield, $1963^{15}$ & 35 & $\mathrm{EGD}, \mathrm{BE}$ & Medical treatment & Cesarean section \\
\hline Karjalainen, $1964^{16}$ & $\begin{array}{l}23 \\
\text { (1st pregnancy) }\end{array}$ & EGD, BE & Medical treatment & Termination \\
\hline Karjalainen, $1964^{16}$ & $\begin{array}{l}23 \\
\text { (2nd pregnancy) }\end{array}$ & EGD & Medical treatment & Premature labor, spontaneous birth \\
\hline Clemendor et al, $1969^{17}$ & $\begin{array}{l}34 \\
\text { (1st pregnancy) }\end{array}$ & BE, Manometry & $\mathrm{BD}$ & Premature labor with fetal death \\
\hline Clemendor et al, $1969^{17}$ & $\begin{array}{l}34 \\
\text { (2nd pregnancy) }\end{array}$ & As above & Medical treatment & Normal spontaneous delivery \\
\hline Clemendor et al, $1969^{17}$ & 22 & BE, Manometry & $\mathrm{BD}, \mathrm{PD}$ & Normal spontaneous delivery \\
\hline Satin et al, $1992^{18}$ & $28 / 38$ & BE, EGD, Manometry & $\mathrm{PD}$ & $\begin{array}{l}\text { Induced vaginal delivery at } 38 \mathrm{wk} \text {. } \\
\text { Healthy baby }\end{array}$ \\
\hline Fiest et al, $1993^{19}$ & $24 / 8$ & BE, Manometry & $\mathrm{PD}$ & Spontaneous at $35 \mathrm{wk}$. Healthy baby \\
\hline Faloon, $1993^{20}$ & 26/prenatal & $\mathrm{BE}$ & $\mathrm{BD}$ & Cesarean section at $36 \mathrm{wk}$. Healthy baby \\
\hline Fassina Osculati, $1995^{21}$ & $23 / 24$ & Autopsy findings & No treatment & $\begin{array}{l}\text { Unexplained sudden maternal death, } \\
\text { megaesophagus }\end{array}$ \\
\hline Aggarwal et al, $1997^{22}$ & $20 / 18$ & BE, EGD, Manometry & $\mathrm{PD}$ & Spontaneous abortion in 7 th month \\
\hline Kalish et al, $1999^{23}$ & $42 / 31$ & EGD & $\mathrm{PN}$ & Spontaneous at $38 \mathrm{wk}$. Healthy baby \\
\hline Ohno et al, $2000^{24}$ & $34 / 27$ & BE, Manometry & No treatment & Intrauterine fetal death \\
\hline Ghoshal and Davies, $2007^{25}$ & $19 y / 33$ & Manometry & NGT (1500 kcal/day) & Induced labor at 37 wk. Healthy baby \\
\hline Pulanic et al, $2008^{26}$ & $30 / 26$ & Not described in report & $\mathrm{PD}$ & Spontaneous at $38 \mathrm{wk}$ \\
\hline Palanivelu et al, $2008^{27}$ & $24 / 2$ nd trimester & $\mathrm{EGD}, \mathrm{BE}$ & LHM & Spontaneous. Healthy baby \\
\hline Díaz Roca et al, $2009^{28}$ & $36 / 26$ & Not described in report & SEMS & Uneventful delivery \\
\hline Wataganara et al, $2009^{29}$ & $39 y / 33$ & EGD & BTI & Cesarean section at $35 \mathrm{wk}$ \\
\hline Paulsen et al, $2010^{30}$ & $34 / 33$ & $\begin{array}{l}\text { CT scan, EGD, } \\
\text { Manometry }\end{array}$ & $\mathrm{PD}$ & Uncomplicated birth \\
\hline $\begin{array}{l}\text { Khandelwal and Krueger, } \\
2011^{31}\end{array}$ & $22 / 15$ & BE, Manometry, EGD & $\mathrm{PN}$, nifedipine & $\begin{array}{l}\text { Cesarean section at } 34 \text { wk. Twins } \\
\text { Intrauterine fetal death of } 1 \text { twin; } \\
\text { healthy } 2 \text { nd twin }\end{array}$ \\
\hline Spiliopoulos et al, $2013^{32}$ & $38 / 29$ & EGD, Manometry & $\mathrm{PN}$ (1215 kcal/day) & Cesarean section at $37 \mathrm{wk}$. Healthy baby \\
\hline Hooft et al, $2015^{33}$ & $23 / 14$ & Manometry & BTI & Spontaneous. Healthy baby \\
\hline Orth, $2015^{34}$ & $30 / 34$ & CT scan & BTI & Spontaneous at $38 \mathrm{wk}$. Healthy baby \\
\hline $\begin{array}{l}\text { Holliday and Baker, } \\
2016^{35}\end{array}$ & $17 / 31$ & MRI scan, BE & BTI & Spontaneous at $37 \mathrm{wk}$ \\
\hline O'Leary et al, $2016^{36}$ & $28 / 32$ & Not described in report & NJT & Cesarean section at $37 \mathrm{wk}$ \\
\hline Neubert and Stickle, $2019^{37}$ & $28 / 22$ & Manometry & BTI & Healthy baby at term \\
\hline Lora Acuña et al, $2019^{38}$ & $26 / 8$ & EGD, BE, Manometry & NGT, PD & Cesarean section at term \\
\hline Narang and Narang, $2019^{39}$ & $35 / 11$ & $\mathrm{EGD}, \mathrm{BE}$ & NGT & Intrauterine fetal death \\
\hline $\begin{array}{l}\text { Vosko et al, } 2021 \\
\text { (the present study) }\end{array}$ & $28 / 29$ & EGD, BE & $\mathrm{PN}$ & $\begin{array}{l}\text { Induced vaginal delivery at } 34 \mathrm{wk} \text {. } \\
\text { Healthy baby }\end{array}$ \\
\hline
\end{tabular}

BE, barium esophagram; BD, Bougie dilation; EGD, esophagogastroduodenoscopy; PD, pneumatic dilation; PN, parenteral nutrition; NGT, nasogastric tube; LHM, laparoscopic Heller myotomy; SEMS, self-expanding metal stent; BTI, botilinum toxin injection; CT, computerized topography; MRI, magnetic resonance imaging; NJT, nasojejunal tube. 
Table 2. Summary of the Benefits and Complications of the Different Modalities for Achalasia Treatment in Pregnancy

\begin{tabular}{|c|c|c|c|c|}
\hline $\begin{array}{l}\text { Type of } \\
\text { treatment }\end{array}$ & Benefits & $\begin{array}{l}\text { Possible complications to the mother and technical } \\
\text { difficulties unique for pregnant patient }\end{array}$ & $\begin{array}{l}\text { Possible complication } \\
\text { to the fetus }\end{array}$ & $\begin{array}{l}\text { Best optional gestational } \\
\text { time for procedure }\end{array}$ \\
\hline $\mathrm{PN}$ & Safe for baby & $\begin{array}{l}\text { Line sepsis }(\sim 17 \%) \\
\text { Deep vein thrombosis }(\sim 8 \%) \\
\text { Catheter occlusion } \\
\text { Catheter dislodgment } \\
\text { Pneumothorax } \\
\text { Electrolyte and trace elements disturbances } \\
\text { High patient compliance needed }\end{array}$ & No reported complications & Any trimester \\
\hline NGT & $\begin{array}{l}\text { Safe for baby and } \\
\text { mostly safe } \\
\text { for mother }\end{array}$ & $\begin{array}{l}\text { Tubes are easily misplaced or dislodged } \\
\text { Perforation of nasopharynx, esophagus, and stomach } \\
\text { Transbronchial insertion } \\
\text { Aspiration } \\
\text { Electrolytes and trace elements disturbances }\end{array}$ & No reported complications & Any trimester \\
\hline BTI & $\begin{array}{l}\text { High response rate } \\
\text { in the } 1 \text { st month } \\
(80-90 \%) \\
\text { Short procedure time }\end{array}$ & $\begin{array}{l}\text { Miscarriage (category } \mathrm{C} \text { medication) } \\
\text { Mediastinitis } \\
\text { Allergic reaction to an egg-based protein } \\
\text { Repeated BTIs—subsequent submucosal fibrosis } \\
\text { that might make invasive therapies more difficult }\end{array}$ & $\begin{array}{l}\text { Possible abortion or fetal } \\
\text { malformations which have } \\
\text { been observed in rabbits }\end{array}$ & $\begin{array}{l}\text { Any trimester } \\
\text { Therapeutic effect wanes } \\
\text { rapidly over time } \\
\text { Best results are at the } \\
\text { 2nd and 3rd trimester } \\
\text { of pregnancy to avoid } \\
\text { repeating treatments }\end{array}$ \\
\hline $\mathrm{PD}$ & $\begin{array}{l}\text { Effective nonsurgical } \\
\text { option } \\
\text { Success rate (50-93\%) } \\
\text { Short procedure time } \\
\text { Short recovery time }\end{array}$ & $\begin{array}{l}\text { Perforation }(0-5 \%) \\
\text { GERD }(15-35 \%)\end{array}$ & $\begin{array}{l}\text { In case of perforation all } \\
\text { the possible surgical } \\
\text { complications including } \\
\text { general anesthesia } \\
\text { complications }\end{array}$ & Any trimester \\
\hline SEMS & $\begin{array}{l}\text { Safe and effective } \\
(83-100 \%)\end{array}$ & $\begin{array}{l}\text { Migration }(5.3 \%) \\
\text { Chest pain }(38.7 \%) \\
\text { GERD }(20 \%) \\
\text { LES fibrosis that might make invasive therapies } \\
\text { more difficult }\end{array}$ & No reported complications & Any trimester \\
\hline POEM & $\begin{array}{l}\text { Highly effective with } \\
\text { possibly the best } \\
\text { sustained success } \\
\text { rates (short-term } \\
90-100 \%, 3 \text { years } \\
88.5 \%, 5 \text { years } 83 \% \text { ) }\end{array}$ & $\begin{array}{l}\text { Perforation } \\
\text { Bleeding } \\
\text { Risk of anesthesia } \\
\text { GERD }\end{array}$ & Unclear & Unclear \\
\hline LHM & $\begin{array}{l}\text { Success rate } \\
(88-98 \%)\end{array}$ & $\begin{array}{l}\text { Poor visualization due to gravid uterus } \\
\text { Uterine injury } \\
\text { Technical difficulties } \\
\text { Decreased uterine blood flow } \\
\text { Risk of general anesthesia } \\
\text { GERD }(14.9 \%)\end{array}$ & $\begin{array}{l}\text { Premature labor from the } \\
\text { increased intra-abdominal } \\
\text { pressure } \\
\text { Increased fetal acidosis or } \\
\text { other unknown effects of } \\
\mathrm{CO}_{2} \text { pneumoperitoneum }\end{array}$ & $\begin{array}{l}\text { 2nd trimester - lowest } \\
\text { risk of teratogenesis, } \\
\text { preterm delivery, } \\
\text { or miscarriage }\end{array}$ \\
\hline
\end{tabular}

PN, parental nutrition; NGT, nasogastric tube; BTI, botulinum toxin injection; PD, pneumatic dilation; SEMS, self-expanding metal stents; POEM, peroral endoscopic myotomy; LHM, laparoscopic Heller myotomy.

mended doses, it is not expected to enter the systemic circulation or reach the maternal-fetal interface. ${ }^{51}$ Endoscopic ultrasound may facilitate localization with direct intramuscular injection, avoiding spillage into blood vessels. ${ }^{52}$

Newman et $\mathrm{al}^{53}$ were the first to report 4 full-term uncomplicated pregnancies in a patient with severe cervical dystonia who 
received BTX-A treatment, without any effect on the pregnancy outcome. Literature reviews have concluded that exposure to botulinum toxin injection (BTI) during pregnancy does not appear to increase the risk of adverse outcome in the fetus. ${ }^{54,55}$

In non-pregnant patients with achalasia, treatment with BTI is often reserved for patients with high surgical risk, short life expectancy, and those who are not candidates for pneumatic dilation (PD), POEM, or surgical myotomy. ${ }^{56}$ However, in pregnant women with achalasia, BTI may serve as a bridge by temporarily improving symptoms until a more permanent treatment can be performed after delivery of the baby. There are several case reports of BTI being used in this way in the literature (Table 1).

\section{Self-expanding Metal Stents}

The temporary use of self-expanding metal stents (SEMS) has been reported in the management of achalasia and other benign esophageal diseases. Complications include migration (5.3\%), chest pain (38.7\%), and reflux (20.0\%), but no perforations or 30-day mortality were reported in achalasia cases. ${ }^{57-59}$ Only 1 case report exists of SEMS use in a pregnant woman with achalasia. Díaz Roca et $\mathrm{al}^{28}$ described a pregnant 36-year-old woman diagnosed with achalasia during her 28th week of gestation. They chose to treat her with SEMS placement and achieved successful relief of symptoms, weight gain, and spontaneous childbirth. The stent was then removed without complication. ${ }^{28}$ Despite this case, the lack of corroborating data, concern over stent migration, and need for fluoroscopic guidance make SEMS placement unattractive for use in pregnancy.

\section{Pneumatic Dilation}

$\mathrm{PD}$ is an effective non-surgical procedure for the treatment of achalasia. ${ }^{1,60}$ The only randomized comparative study between PD and surgery, carried out by the European Achalasia Trial Investigators Group in 2011, showed similar results for both techniques over a follow-up period of 2 years. ${ }^{61}$ A meta-analysis found that both techniques, PD and laparoscopic Heller myotomy (LHM), were effective in the treatment of achalasia. ${ }^{62}$ Candidates for PD should be those for whom surgery is not contraindicated taking into account that the most severe complication of this technique is esophageal perforation, which occurs in approximately $1.9 \%$ (range $0.0-$ $16.0 \%)^{63,64}$

In 1969 , Clemendor et $\mathrm{al}^{17}$ were the first to report a successful case of $\mathrm{PD}$ for achalasia during pregnancy, which was performed at 24 weeks gestation, followed by an uneventful delivery of a healthy baby at 36 weeks. Prior to that, several cases of Bougie dilation had been reported. Since then, 6 additional cases of PD have been reported (Table 1). In all of these cases healthy babies were delivered suggesting that PD is an effective and safe therapeutic option. With 7 cases reports, there is more evidence to support the use of PD than any other treatment modality.

No studies have clearly shown what the optimal balloon size for PD is in achalasia patients overall, let alone in pregnant ones; nor are there studies comparing balloon sizes used in PD for nonpregnant versus pregnant achalasia patients. Therefore it is not clear what size balloon should be used for PD in pregnant women. Using the smallest size ( $30 \mathrm{~mm}$ diameter) balloon may decrease the risk of perforation in these high-risk patients, although this may also limit the therapeutic benefit.

\section{Peroral Endoscopic Myotomy}

POEM is quickly becoming a safe and effective treatment option for patients with achalasia with better efficacy rates compared to surgery. ${ }^{65,66}$ As the effectiveness of POEM has been established over the past few years, and its complications are comparable to or better than that of surgery, it may be an effective treatment for achalasia during pregnancy. However, at the current time, we are hesitant to comment on its safety or efficacy during pregnancy as there are no case reports of its use in pregnant women with achalasia. As POEM continues to become more widely practiced, it may only be a matter of time until it is used in such a patient. The risks of POEM include perforation, as well as the need for intubation and anesthesia, all of which add to the risk of performing it in a pregnant woman. ${ }^{65}$

\section{Surgical Myotomy}

The timing and the type of surgery are 2 important issues to consider before any surgery during pregnancy due to concerns over fetal maturity and maternal safety. In general, surgery is safest in the second trimester because the risk of spontaneous abortion or preterm delivery is less than $5 \%$ at this time. During the first trimester, there is a risk that anesthetic medications may impair fetal organogenesis and lead to abortions in up to $12 \%$. During the third trimester, surgery may precipitate labor in up to $40 \%$ of patients. ${ }^{67}$

Palanivelu et al ${ }^{68}$ reported on 19 different laparoscopic surgical procedures performed in pregnant patients during the second trimester, including one case of LHM after the patient had no response to PD. All the laparoscopic procedures were successful without mortality, morbidity, or complications for either mother or child. ${ }^{68}$ However, others emphasize that pregnant women remain at risk for perinatal 
complications, including fetal loss, and that surgeries should be postponed until after delivery if at all possible. ${ }^{69}$ The case by Palanivelu et $\mathrm{al}^{27}$ remains the only case report of LHM during pregnancy. Although the patient did well and eventually delivered a healthy baby, there remains insufficient evidence to recommend LHM during pregnancy at the present time.

\section{Case Presentation}

Some of the diagnostic and therapeutic dilemmas discussed above are illustrated in the following case report. A 28-year old woman was referred to our institution at 29 weeks of gestation due to frequent vomiting since the start of her pregnancy. Endoscopy revealed a dilated esophagus containing food without any strictures or masses (Fig. 1). She was treated conservatively for achalasia, but was re-admitted 2 weeks later due to inability to eat and recurrent hematemesis. After a discussion of the therapeutic options in pregnancy, she opted for total parenteral nutrition until delivery. She was admit- ted again at 34 weeks of gestation with pre-eclampsia. Labor was induced, and she delivered a healthy $1.75 \mathrm{~kg}$ baby by vaginal delivery.

At 5 weeks postpartum, the patient underwent LHM with Dor fundoplication. However, the treatment provided only a few weeks of relief. A subsequent barium esophagram revealed significant delay in esophageal emptying and a tapered lower esophagus ("bird's beak" sign). Upper endoscopy showed a dilated sigmoid-shaped esophagus with retained food and secretions. She had continued worsening of her symptoms with a 17-kg weight loss. Approximately 6 months later, she was admitted urgently with severe hematemesis. Computed tomographic scan revealed food extending from the esophagogastric junction upwards to the proximal esophagus (Fig. 2). Upper endoscopy revealed a dilated esophagus with food and bleeding from stasis ulcerations. She underwent esophagectomy (Fig. 3) with a gastric pull-through, and a jejunal feeding tube was placed. Eight weeks later, she had good oral intake and the tube was removed.

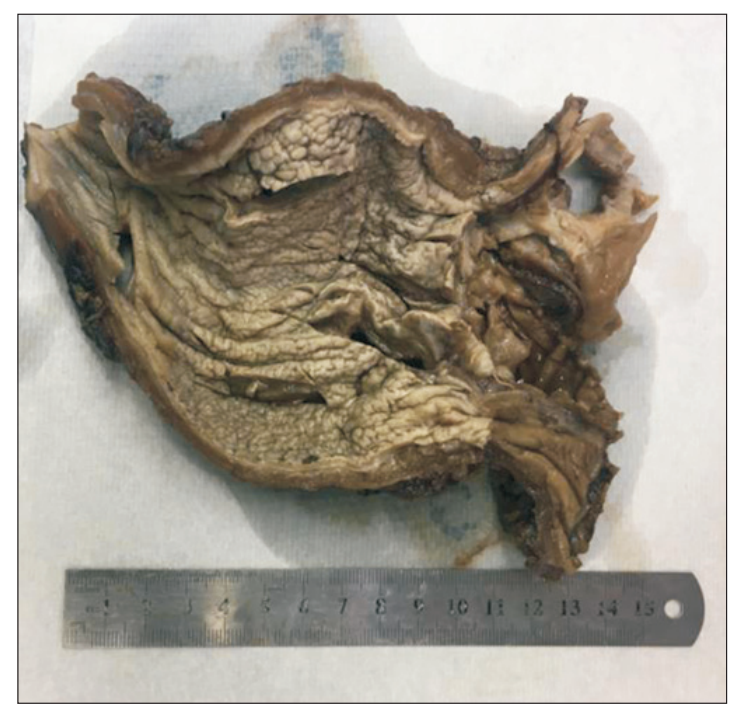

Fiğure 3. Esophageal resection specimen showing megaesophagus.
Figure 1. Esophagogastroduodenoscopy revealed a dilated esophagu

containing food, but no mass or strictures.

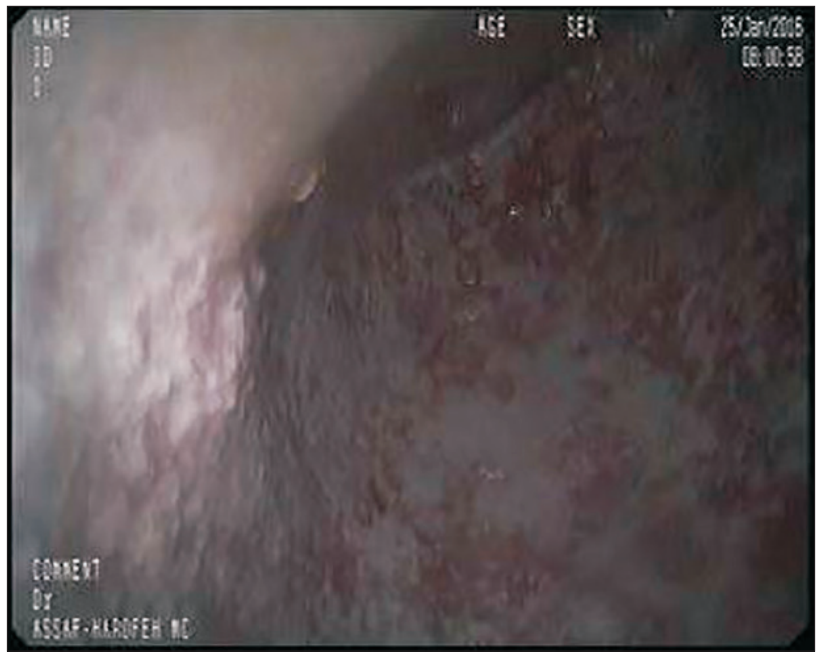

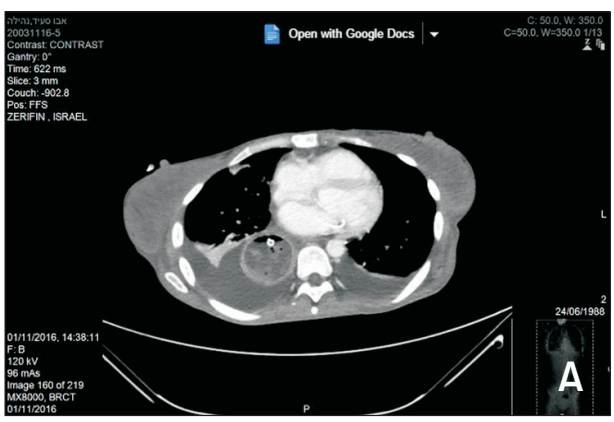

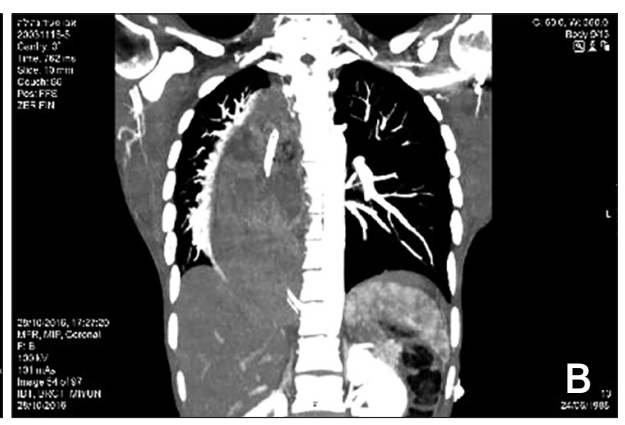

Figure 2. Computed tomographic imaging revealed megaesophagus with food extending from the proximal esophagus to the esophagogastric junction. (A) Cross-sectional view. (B) Coronal view. 


\section{Proposed Therapeutic Management Algo- rithm}

Given the rarity of achalasia in pregnancy, and the various treatments available for achalasia in general, no guidelines exist for the management of achalasia in pregnancy. Therefore, we recommend that the decision should be individualized for each case, considering both the welfare of mother and fetus. Individual factors to be considered include the age of the patient, nutritional status, gestational age, surgical risk, comorbidities, subtype of achalasia, patient preference, esophageal anatomy, and the local expertise available. Most of the recent case reports describe good outcomes for both mother and baby, although this may reflect an element of publication bias.

In Figure 4, we propose an algorithm for the management of achalasia based on the available literature. In general, treatment should be aimed at maintaining the patient's nutritional status throughout pregnancy with the goal of delivering a healthy baby at term. This should be achieved through the use of bridging treatments to reach this goal. Definitive treatment of achalasia should ideally be performed after completion of a successful pregnancy.

For patients with inadequate nutritional intake during pregnancy, NGT feedings seem to be the safest option and is recommended as an initial therapy for nutritional replacement and support. The main concern with NGT use is its tolerability, especially for prolonged periods. For those who do not want or cannot tolerate a NGT, PN can be a reasonable treatment option. $\mathrm{PN}$ is a relatively safe and effective method for reversing maternal malnutrition and promoting normal fetal growth and development, although it is not free of complications.

If significant achalasia symptoms persist, BTI appears to be a safe bridging modality until delivery of the baby. In patients who refuse BTI or for whom BTI has failed, PD is an alternative as it has more successful cases reported in the literature than any other modality. Given the risk of perforation, it should be carried out in hospitals with experienced gastroenterologists and surgeons.

Finally, if bridging modalities do not provide adequate relief, LHM can be considered, especially during the 2nd trimester. However, since it is an elective procedure with all of the risks of surgery, we recommend that LHM should be delayed until after delivery if at all possible. Given the growing evidence that POEM is as effective and safe as LHR, it may also be an option in pregnant achalasia patients requiring definitive treatment. However, as there have been no reports of its use in pregnant women to date, we cannot definitively recommend its use at this time.

Adequate monitoring of the therapeutic response to achalasia treatment is also limited by pregnancy. Performing additional invasive procedures, such as post-treatment barium esophagram, endoscopy, or manometry, should be avoided if possible. Instead, therapeutic success should be based on clinical parameters such as symptom improvement, weight gain, and fetal development.

\section{Conclusions}

Achalasia during pregnancy is a rare clinical situation. Pregnant women suffering from achalasia represent a diagnostic and

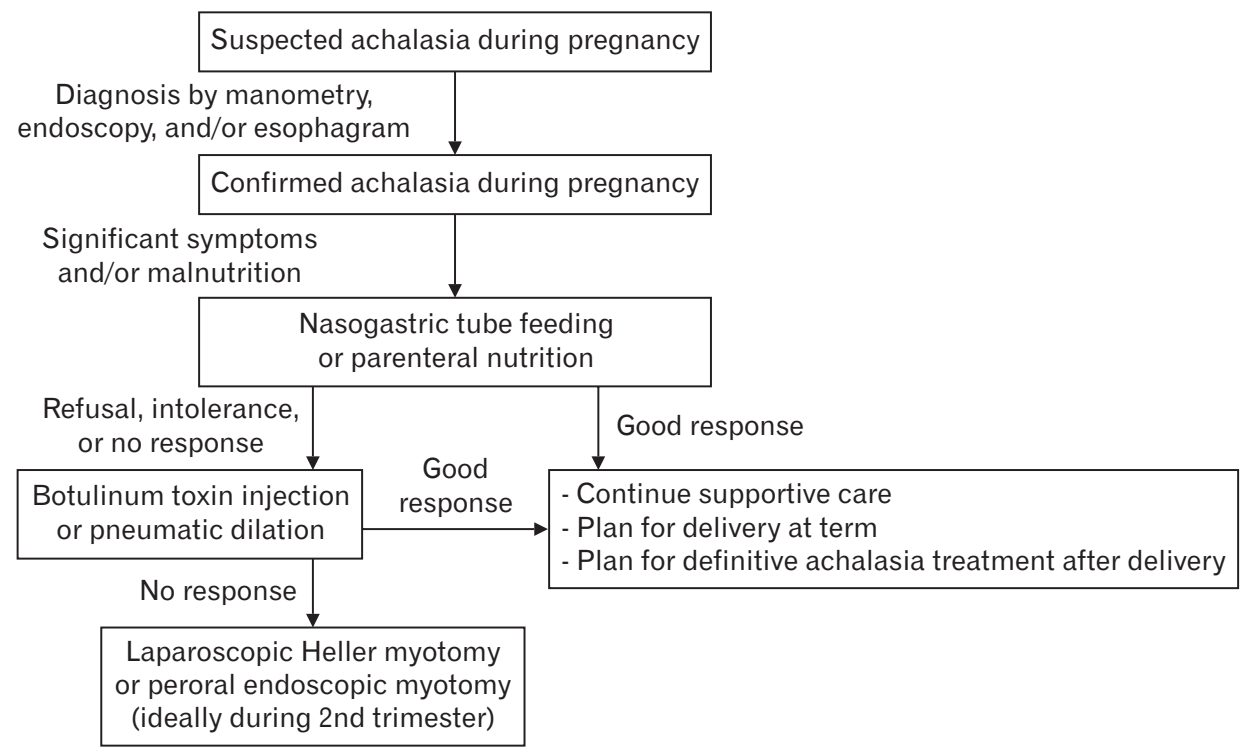

Figure 4. Proposed algorithm for the management of achalasia during pregnancy based on a thorough review of the literature. 
therapeutic challenge as a delay in the diagnosis and treatment can have serious implications for maternal health and fetal viability. A multidisciplinary team including gastroenterologist, obstetrician, dietician, radiologist, and surgeon is needed for decision making. A thorough discussion with the patient of the expected risks and benefits for each treatment modality is required, with special concern for her wishes regarding fetal safety. In general, a conservative approach should be adopted with bridging therapies performed until after delivery when definitive treatment will be safest.

\section{Financial support: None.}

\section{Conflicts of interest: None.}

Author contributions: Sergei Vosko contributed to the conception and design of the work, the acquisition, analysis and interpretation of the data, and drafting the work; Daniel L Cohen contributed to the acquisition, analysis and interpretation of the data, drafting the work, and revising it critically for important intellectual content; Ortal Neeman contributed to the conception and design of the work, the acquisition, analysis, and interpretation of the data; Shai Matalon contributed to the conception and design of the work, the acquisition, analysis, and interpretation of the data, and revising it critically for important intellectual content; Efrat Broide contributed to the conception and design of the work, the acquisition, analysis, and interpretation of the data, and revising it critically for important intellectual content; and Haim Shirin contributed to the acquisition, analysis, interpretation of the data, drafting the work, and revising it critically for important intellectual content. All the authors have contributed significantly, and are in agreement with the content of the manuscript. All reviewed the final submission and provided revisions for the final version.

\section{References}

1. Vaezi MF, Pandolfino JE, Yadlapati RH, Greer KB, Kavitt RT. ACG clinical guidelines: diagnosis and management of achalasia. Am J Gastroenterol 2020;115:1393-1411.

2. Furuzawa-Carballeda J, Torres-Landa S, Valdovinos MA, Coss-Adame E, Martin Del Campo LA, Torres-Villalobos G. New insights into the pathophysiology of achalasia and implications for future treatment. World J Gastroenterol 2016;22:7892-907.

3. Mayberry JF, Atkinson M. Achalasia and pregnancy. Br J Obstet Gynaecol 1987;94:855-859.

4. Vogel T, Wrobel RM, Graupner O, Lobmaier S, Feussner H, Kuschel B. Esophageal achalasia and pregnancy: own observations in 43 patients and a review of the literature. Arch Gynecol Obstet 2018;298:511-519.
5. Rottenstreich A, Brodie R, Marom G, Jacob H, Benson A, Mintz Y. Reproductive outcomes among women of childbearing age with achalasia after peroral endoscopic myotomy: a single-center experience. J Laparoendosc Adv Surg Tech A Published Online First: 13 Jul 2020. doi: 10.1089/lap.2020.0379.

6. Becker J, Niebisch S, Ricchiuto A, et al. Comprehensive epidemiological and genotype-phenotype analyses in a large European sample with idiopathic achalasia. Eur J Gastroenterol Hepatol 2016;28:689-695.

7. Richter JE. High-resolution manometry in diagnosis and treatment of achalasia: help or hype. Curr Gastroenterol Rep 2014;16:420.

8. Ulmsten U, Sundström G. Esophageal manometry in pregnant and non pregnant women. Am J Obstet Gynecol 1978;132:260-264.

9. American College of Obstetricians and Gynecologists' Committee on Obstetric Practice. Committee opinion No. 656 summary: guidelines for diagnostic imaging during pregnancy and lactation. Obstet Gynecol 2016;127:418.

10. Friedel D, Stavropoulos S, Iqbal S, Cappell MS. Gastrointestinal endoscopy in the pregnant woman. World J Gastrointest Endosc 2014;6:156167.

11. Cappell MS. Risks versus benefits of gastrointestinal endoscopy during pregnancy. Nat Rev Gastroenterol Hepatol 2011;8:610-634.

12. Roques F. Pregnancy associated with cardiospasm. J Obstet Gynaecol Br Emp 1932;39:550-557.

13. Lindert MC. Cardiospasm in association with pregnancy. Am J Obstet Gynecol 1956;72:1137-1142.

14. Stroup PE. Achalasia of the esophagus during pregnancy. Obstet Gynecol 1961;92:941.

15. Bloomfield RD. Pregnancy and achalasia. Am J Obstet Gynecol 1963;86:1074-1078.

16. Karjalainen A. Achalasia of the esophagus in association with pregnancy. Acta Obstet Gynecol Scand 1964;43:19-27.

17. Clemendor A, Sall S, Harbilas E. Achalasia and nutritional deficiency during pregnancy. Obstet Gynecol 1969;33:106-113.

18. Satin AJ, Twickler D, Gilstrap LC 3rd. Esophageal achalasia in late pregnancy. Obstet Gynecol 1992;79(Pt 2):812-814.

19. Fiest TC, Foong A, Chokhavatia S. Successful balloon dilation of achalasia during pregnancy. Gastrointest Endosc 1993;39:810-812.

20. Faloon T. Achalasia in pregnancy. A case of a rare coexistence. Can Fam Physician 1993;39:1182-1184, 1186.

21. Fassina G, Osculati A. Achalasia and sudden death: a case report. Forensic Sci Int 1995;75:133-137.

22. Aggarwal R, Shahi HM, Misra A. Esophageal achalasia presenting during pregnancy. Indian J Gastroenterol 1997;16:72-73.

23. Kalish RB, Garry D, Figueroa R. Achalasia with Candida esophagitis during pregnancy. Obstet Gynecol 1999;94(5 Pt 2):850.

24. Ohno Y, Kawai M, Shibata Y, Arii Y. Esophageal achalasia in pregnancy. Am J Perinatol 2000;17:53-55.

25. Ghoshal S, Davies AJ. An unusual case of vomiting and weight loss in pregnancy - oesophageal achalasia. J Obstet Gynaecol 2007;27:622-623.

26. Pulanic R, Kalauz M, Opacic M, Rustemovic N, Brkic T. Successful pneumatic dilation of achalasia in pregnancy. Dig Liver Dis 2008;40:600601. 
27. Palanivelu C, Rangarajan M, Maheshkumaar GS, Parthasarathi R. Laparoscopic Heller's cardiomyotomy for achalasia of the cardia in a pregnant patient. Ann Acad Med Singap 2008;37:442-443.

28. Díaz Roca AB, Sampascual SB, Calderón AJ, et al. Self-expanding esophageal prostheses as an alternative temporary treatment for achalasia. Gastrointestl Endosc 2009;69:980.

29. Wataganara T, Leelakusolvong S, Sunsaneevithayakul P, Vantanasiri C. Treatment of severe achalasia during pregnancy with esophagoscopic injection of botulinum toxin A: a case report. J Perinatol 2009;29:637-639.

30. Paulsen V, Syversveen T, Kett K. An unusual cause of acute airway obstruction. Tidsskr Nor Laegeforen 2010;130:2241.

31. Khandelwal M, Krueger C. Diaphragmatic hernia after laparoscopic esophagomyotomy for esophageal achalasia in pregnancy. ISRN Gastroenterol 2011;2011:871958.

32. Spiliopoulos D, Spiliopoulos M, Awala A. Esophageal achalasia: an uncommon complication during pregnancy treated conservatively. Case Rep ObstetGynecol 2013;2013:639698.

33. Hooft N, Schmidt ES, Bremner RM. Achalasia in pregnancy: botulinum toxin A injection of lower esophageal sphincter. Case Rep Surg 2015;2015:328970.

34. Orth TA. Achalasia during pregnancy treated with botulinum toxin A injection at the lower esophageal sphincter. Med J Obstet Gynecol 2015;3:1058.

35. Holliday N, Baker S. Intrasphincteric botulinum toxin injections to treat achalasia diagnosed in pregnancy: a case report. J Reprod Med 2016;61:615-617.

36. O'Leary B, Curran S, Broderick V. A hard case to swallow: achalasia in pregnancy. Ir Med J 2016;109:489.

37. Neubert ZS, Stickle ET. Bridging therapy for achalasia in a second trimester pregnant patient. J Family Med Prim Care 2019;8:289-297.

38. Lora Acuña F, Parra Izquierdo V, Espinosa C, et al. [Endoscopic dilatation in a patient with achalasia during pregnancy:case report and review of the literature.] Rev Gastroenterol Peru 2019;39:70-73. [Spanish]

39. Narang U, Narang L. Oesophageal achalasia diagnosed in pregnancy in a woman managed as severe hyperemesis refractory to medical management. J Obstet Gynaecol 2019;39:1032-1033.

40. American Gastroenterological Association. American Gastroenterological Association medical position statement: parenteral nutrition. Gastroenterology 2001;121:966-999.

41. Wolk RA, Rayburn WF. Parenteral nutrition in obstetric patients. Nutr Clin Pract 1990;5:139-152.

42. Peled Y, Melamed N, Hiersch L, Pardo J, Wiznitzer A, Yogev Y. The impact of total parenteral nutrition support on pregnancy outcome in women with hyperemesis gravidarum. J Matern Fetal Neonatal Med 2014;27:1146-1150.

43. Caruso A, De Carolis S, Ferrazzani S, Trivellini C, Mastromarino C, Pittiruti M. Pregnancy outcome and total parenteral nutrition in malnourished pregnant women. Fetal Diagn Ther 1998;13:136-140.

44. Meadows N. Monitoring and complications of parenteral nutrition. Nutrition 1998;14:806-808.

45. Folk JJ, Leslie-Brown HF, Nosovitch JT, Silverman RK, Aubry RH. Hyperemesis gravidarum: outcomes and complications with and without total parenteral nutrition. J Reprod Med 2004;49:497-502.

46. Hsu JJ, Clark-Glena R, Nelson DK, Kim CH. Nasogastric enteral feeding in the management of hyperemesis gravidarum. Obstet Gynecol 1996;88:343-346.

47. Godil A, Chen YK. Percutaneous endoscopic gastrostomy for nutrition support in pregnancy associated with hyperemesis gravidarum and anorexia nervosa. JPEN J Parenter Enteral Nutr 1998;22:238-241.

48. Vaezi MF, Richter JE. Current therapies for achalasia: comparison and efficacy. J Clin Gastroenterol 1998;27:21-35.

49. Bortolotti M, Mari C, Lopilato C, Porrazzo G, Miglioli M. Effects of sildenafil on esophageal motility of patients with idiopathic achalasia. Gastroenterology 2000;118:253-257.

50. Botox [product monograph]. Irvine, CA: Allergan Inc 2011.

51. Botox Cosmetic [product monograph]. Irvine, CA: Allergan Inc 2011.

52. Hoffman BJ, Knapple WL, Bhutani MS, Verne GN, Hawes RH. Treatment of achalasia by injection of botulinum toxin under endoscopic ultrasound guidance. Gastrointest Endosc 1997;45:77-79.

53. Newman WJ, Davis TL, Padaliya BB, et al. Botulinum toxin type A therapy during pregnancy. Mov Disord 2004;19:1384-1385.

54. Tan M, Kim E, Koren G, Bozzo P. Botulinum toxin type A in pregnancy. Can Fam Physician 2013;59:1183-1184.

55. Li W, Tang M. Application of botulinum toxin in pregnancy and its impact on female reproductive health. Expert Opin Drug Saf 2020:19:8391.

56. Kumar AR, Schnoll-Sussman FH, Katz PO. Botulinum toxin and pneumatic dilation in the treatment of achalasia. Tec Gastrointest Endosc 2014;16:10-19.

57. Zhao JG, Li YD, Cheng YS, et al. Long-term safety and outcome of a temporary self-expanding metallic stent for achalasia: a prospective study with a 13-year single-center experience. Eur Radiol 2009;19:1973-1980.

58. Cheng YS, Ma F, Li YD, et al. Temporary self-expanding metallic stents for achalasia: a prospective study with a long-term follow-up. World J Gastroenterol 2010;16:5111-5117.

59. Sharma P, Kozarek R, Practice Parameters Committee of American College of $\mathrm{G}$. Role of esophageal stents in benign and malignant diseases. Am J Gastroenterol 2010;105:258-273.

60. Vaezi MF, Richter JE. Diagnosis and management of achalasia. American College of Gastroenterology Practice Parameter Committee. Am J Gastroenterol 1999;94:3406-3412.

61. Boeckxstaens GE, Annese V, des Varannes SB, et al. Pneumatic dilation versus laparoscopic Heller's myotomy for idiopathic achalasia. N Engl J Med 2011;364:1807-1816.

62. Weber CE, Davis CS, Kramer HJ, Gibbs JT, Robles L, Fisichella PM. Medium and long-term outcomes after pneumatic dilation or laparoscopic Heller myotomy for achalasia: a meta-analysis. Surg Laparosc Endosc Percutan Tech 2012;22:289-296.

63. Vela MF, Richter JE, Khandwala F, et al.The long-term efficacy of pneumatic dilatation and Heller myotomy for the treatment of achalasia. Clin Gastroenterol Hepatol 2006;4:580-587.

64. Eckardt VF, Kanzler G, Westermeier T. Complications and their impact after pneumatic dilation for achalasia: prospective long-term follow-up study. Gastrointest Endosc 1997;45:349-353. 
65. Feng J, Ali RW, Hao JY, Kong GX, Yang LH, Huang XJ. Peroral endoscopic myotomy formotility disorders. Esophagus 2020;17:11-18.

66. Youn YH, Minami H, Chiu PW, Park H. Peroral endoscopic myotomy for treating achalasia and esophageal motility disorders. J Neurogastroenterol Motil 2016;22:14-24.

67. Van De Velde M, De Buck F. Anesthesia for non-obstetric surgery in the pregnant patient. Minerva Anestesiol 2007;73:235-240.
68. Palanivelu C, Rangarajan M, Senthilkumaran S, Parthasarathi R. Safety and efficacy of laparoscopic surgery in pregnancy: experience of a single institution. J Laparoendosc Adv Surg Tech A 2007;17:186-190.

69. Corneille MG, Gallup TM, Bening T, et al. The use of laparoscopic surgery in pregnancy: evaluation of safety and efficacy. Am J Surg 2010;200:363-367. 